\title{
ASPECTOS METODOLÓXICOS DA ELABORACIÓN DO CORPUS GONDOMAR
}

\section{Ernesto González Seoane}

Instituto da Lingua Galega, Universidade de Santiago de Compostela Rosario Álvarez Instituto da Lingua Galega, Universidade de Santiago de Compostela DOI: $10.17075 /$ cbfc. 2020.005 

Gondomar é resultado dun proxecto de investigación, desenvolvido no Instituto da Lingua Galega da Universidade de Santiago de Compostela, co obxectivo de reunir nun repositorio dixital a produción escrita en lingua galega ao longo dos séculos XVI, XVII e XVIII e, ao tempo, elaborar e poñer ao dispor dos investigadores e do público interesado unha serie de ferramentas para a súa interpretación e estudo.

Con este fin, Gondomar ofrece un catálogo depurado de textos do galego medio, enriquecido con novas e significativas contribucións e cunha caracterización dos textos que ten en conta, por unha banda, a súa clasificación tipolóxica e, por outra, os seus trazos lingüísticos. Este catálogo aspira a servir para dar noticia do corpus textual da época na súa integridade, anotando os elementos falsos e apócrifos así como os diferentes graos de hibridación lingüística que presentan os textos, e mais para dar a cońecer a súa localización e as referencias bibliográficas relativas a cada un deles.

Por outra banda, Gondomar ofrece tamén unha edición dos textos xunto coa reprodución fotográfica dos orixinais ou das copias que serviron de base para realizala. A lectura e edición dos textos foi realizada polos membros do equipo de investigación, con criterios acordes con outros proxectos científicos semellantes e, en todo caso, uniformes e sistemáticos. A edición inclúe sempre dúas versións, unha transcrición paleográfica ou moi conservadora dos textos e unha edición interpretativa, con posibilidade de navegar entre unha e outra.

Forman igualmente parte do proxecto Gondomar o desenvolvemento de ferramentas para a explotación áxil e fiable dos datos lingüísticos contidos no corpus; a elaboración de estudos que os analicen desde un punto de vista lingüístico e pragmático, indaguen nas condicións en que estes textos se produciron e reconstrúan a súa peripecia histórica; e a presentación dos manuais que resumen as normas seguidas na transcrición, edición, etiquetación e lematización, e que son accesibles a través da web do proxecto (Álvarez / González Seoane 2017a). 


\section{TIPOLOXÍA DOS TEXTOS GALEGOS DA IDADE MODERNA ${ }^{1}$}

Como é ben cońecido, o nivel de cultivo atinxido polo galego ao longo da Idade Moderna presenta unhas cifras absolutas moi modestas. O reducido volume de textos producidos (ou conservados) nun período de tempo tan extenso determina que a densidade de textos por unidade de tempo sexa moi baixa. Por outra banda, a irregular distribución dos textos no eixe cronolóxico provoca a existencia de numerosas lagoas temporais, algunhas delas moi extensas, para as que non contamos con ningún testemuño escrito.

Cómpre advertir ademais que, aínda que con algunha excepción notable, se trata de textos breves, moitos deles de circunstancias, creados para conmemorar un acontecemento destacado ou para concorrer a un certame, e concibidos para seren empregados nunha celebración ou data sinalada, pero non para seren conservados para a posteridade.

Polo demais, boa parte dos textos conservados é de autor descońecido. Esta circunstancia é nalgúns casos consubstancial ao propio xénero ou tradición textual en que se inscriben, caso, por exemplo, dos vilancicos. Polo que se refire aos autores coñecidos, cabe salientar que se trata de produtores letrados, algúns deles funcionarios, outros vinculados a determinados círculos nobiliarios e eclesiásticos. Un deles é, sen dúbida, o creado arredor da figura singular de Diego Sarmiento de Acuña, primeiro conde de Gondomar (cfr. Álvarez / Rodríguez Montederramo 2002, 2004, 2005). Outros círculos corresponden a pequenos grupos de ilustrados, como o que reúne a tres dos irmáns Feijoo Montenegro (Benito, Plácido e Anselmo) e a Sarmiento, por unha banda, e o formado por María Francisca de Isla, Diego Antonio Cernadas y Castro e José Cornide Saavedra, por outro. Finalmente, outro dos núcleos produtores de textos en galego aparece vinculado á Compañía de Xesús. Tal e como teñen mostrado autores como Cortijo / Zugasti (2016) e González Montañés (2007), semella evidente que o galego ocupaba un certo papel nalgunhas das actividades desenvolvidas nos colexios que a Compañía tińa en Galicia, e de xeito particular no teatro escolar producido en Lemos e Monterrei (cf. ademais Álvarez / González Seoane 2015, esp. 21-23).

1 Este apartado é unha reelaboración parcial de Álvarez / González Seoane (2016). 
Nalgúns casos, o emprego do galego vén imposto pola propia tradición textual. Isto é o que ocorre cos vilancicos en galego ou de galegos, e tamén cos parlamentos en galego (ou en algo que pretende pasar por galego) inseridos en entremeses e comedias, que permiten aos seus autores caracterizar un personaxe fortemente estereotipado (cfr. González Seoane 2019). Noutros casos, en cambio, especialmente nas pezas de maior ambición literaria, a adopción do galego é un indicador dunha convicción firme por parte dos seus autores acerca da dignidade estética do galego e da súa aptitude para ser vehículo para a expresión de sentimentos elevados.

Se consideramos a produción textual conservada atendendo á súa tipoloxía, axiña nos decatamos de que, con independencia da clasificación que se adopte, son moitos os xéneros ou tipos de texto para os que non contamos con ningunha mostra. Malia todo, advírtese tamén unha marcada dispersión tipolóxica, o que se traduce nunha moi baixa densidade por tipo de texto. Este desenvolvemento irregular do cultivo do galego ao longo da Idade Moderna non resiste a comparanza, nin en termos cuantitativos e nin cualitativos, coa que presentan neste mesmo período linguas con tradicións consolidadas e ininterrompidas.

En calquera caso, resulta do máximo interese afondar nunha caracterización tipolóxica sistemática dos textos do corpus por mor das implicacións de carácter lingüístico e sociolingüístico que comporta. Non convirá esquecer, neste sentido, que o abano de tipos textuais cuberto por unha lingua nun momento dado da súa historia vén sendo considerado, xunto co tipo de temas tratados, un claro indicador do nivel de cultivo e de elaboración atixindos por esa lingua, así como da función que esta desempeña e da consideración social de que goza dentro da súa comunidade (Kloss 1967, 34; Joseph 1978, 76-79). Pero ademais, como puxeron de relevo as propostas metodolóxicas desenvolvidas no marco das chamadas "tradicións discursivas", as clasificacións textuais adquiren unha relevancia que transcende o puro interese taxonómico. Neste sentido, por máis que de ningún xeito se deba identificar "tradición discursiva" e "tipo de texto", a identificación e caracterización dos tipos de texto poden proporcionarnos o marco primario ou básico para unha correcta valoración dos datos lingüísticos (Kabatek 2006, 165; 2007, 337). Así, o tipo de texto pode impoñer certos elementos estruturais ou formais. Pénsese, por exemplo, nos condicionantes métricos, rítmicos e estróficos dos textos poéticos, ou na estrutura recorrente que caracteriza os epistolares. 
Noutras ocasións, o xénero ou tipo de texto pode propiciar a aparición de certas formas lingüísticas e dificultar a doutras. Así, os textos teatrais e dialogados favorecen, por exemplo, o emprego de formas de primeira e segunda persoas, ou do imperativo, que teñen moita menor presenza en textos narrativos. Finalmente, o tipo de texto pode determinar a adopción por parte do seu autor dunha certa variedade ou rexistro en función da súa estratexia discursiva.

Estas consideracións teñen unha especial importancia en casos coma o que nos ocupa, en que o cultivo dunha lingua aparece fortemente restrinxido tanto cuantitativa como cualitativamente a un elenco moi limitado de tipos textuais.

a) Adscrición xenérica

Unha primeira clasificación, ben coñecida e habitual nas tipoloxías adoptadas na construción de corpus textuais, é a que permite distinguir entre textos literarios e non literarios. Polo que se refire ao noso corpus, entre os primeiros cabe establecer os seguintes grupos:

- Poesía culta, de corte académico, maioritariamente profana, dentro da que ocupa un lugar central a poesía de circunstancias. Pertencen a este grupo as pezas compostas para festexar un acontecemento gozoso ou para lamentar un feito luctuoso, para participar en xustas e certames literarios, ou simplemente para afagar un personaxe poderoso. A poesía culta está representada ao longo de toda a Idade Moderna, desde finais do século XVI ata as postrimerías do XVIII. En todo caso, cómpre sinalar que a concentración de textos se incrementa conforme avanzamos na liña do tempo, ata atinxir unha maior densidade na segunda metade do setecentos.

- Poesía popular e popularizante. Trátase, por regra xeral, de pequenas pezas, maioritariamente coplas, transmitidas oralmente e rexistradas por algún autor. A elas habería que engadir as compostas a imitación deste modelo, como as coplas que conforman o Coloquio de veinticuatro gallegos rústicos de Sarmiento (1746).

- Poesía cancioneiril. Forman parte deste grupo algúns poemas presentes en diversos cancioneiros hispánicos, principalmente casteláns, do século XVI. 
Trátase de textos de transmisión dubidosa, escritos nun galego estereotipado ou fortemente hibridado.

- Vilancicos. Conforman este grupo as composicións "en galego" ou "de galegos" que eran cantadas, sobre todo en Nadal e Reis, en igrexas e catedrais, polo xeral fóra do territorio galegófono, en España, Portugal ou a América Hispánica. Aínda que os vilancicos comparten algunhas das características sinaladas a propósito doutros grupos (transmisión irregular, hibridación lingüística e, ocasionalmente, intencionalidade paródica), constitúen unha tradición ben diferenciada, o que fai aconsellable mantelos como tipo á parte.

- Textos dramáticos e dialogados. Integran este grupo algúns diálogos e pezas de carácter entremesístico, escritos enteiramente en galego e, ademais, fragmentos e parlamentos en galego incluídos en obras teatrais en castelán ou plurilingües, producidas tanto dentro coma fóra de Galicia.

- Textos en prosa. Son moi escasas as mostras conservadas.

Polo que se refire aos textos non literarios, cabe distinguir os seguintes tipos:

- Prosa documental, maioritariamente notarial. Trátase da manifestación epigonal dunha tradición iniciada no século XIII e mantida de maneira continuada ata o comezo do seu declive na segunda metade do Xv. Aínda así, o galego subsiste, aínda que moi marxinalmente, neste tipo de textos ata ben entrado o século Xvi.

- Correspondencia privada. Pertencen a este tipo un pequeno conxunto de cartas privadas, entre as cales cabe salientar dous grupos, datados entre 1527 e 1530 e entre 1567 e 1626 e dirixidos, respectivamente, a Pedro Álvarez Soutomaior, terceiro conde de Camiña, e a Diego Sarmiento de Acuña, conde de Gondomar.

- Textos historiográficos. Neste grupo intégranse algunhas memorias e textos cronísticos que constitúen falsificacións de textos pretendidamente antigos realizadas ao longo do século xviI e tamén algúns outros textos que chegaron a nós a través de copias realizadas con posterioridade á súa composición. 
- Refráns e proverbios. Deste tipo de textos consérvanse algunhas compilacións, como a realizada por Hernán Núnez a mediados do século XVI.

- Glosas e anotacións marxinais. Trátase de framentos, frases ou palabras integradas en textos escritos noutro idioma ou anotadas á marxe de escritos e documentos.

b) Ámbito de difusión

Outro criterio de gran relevancia polas súas implicacións, tanto na esfera do propiamente lingüístico coma no dominio sociolingüístico, é o ámbito de difusión primario dos textos. Este criterio permítenos establecer un eixe en cuxos extremos se situarían, respectivamente, os textos concibidos orixinariamente como privados (por exemplo, as cartas particulares) e aqueloutros creados para a súa difusión pública (por exemplo, os textos publicados e difundidos a través da imprenta). Entremedias estarían os textos de contido non estritamente privado pero que, aínda así, non foron pensados para a súa difusión pública (por exemplo, boa parte da prosa documental) e, por outra banda, os textos que, por razóns que cumpriría analizar detalladamente, non foron dados á imprenta, pero que foron creados para ser lidos por un círculo restrinxido de persoas.

A contraposición entre textos públicos e privados solápase parcialmente coa distinción entre impresos e manuscritos. Así, os textos privados e os semipúblicos (dirixidos a un público restrinxido) aparecen, como é lóxico, en forma manuscrita; os textos impresos teñen, tamén obviamente, carácter público; non obstante, non todos os textos manuscritos teńen necesariamente carácter privado ou semipúblico.

c) Autonomía

Tomando como base este criterio podemos distinguir tres grupos:

- Textos autónomos, completos e independentes, que non forman parte dunha obra máis extensa. Nesta categoría poderíanse integrar tamén os textos autónomos que figuran en antoloxías ou compilacións de diverso 
tipo, pero que non manteñen unha relación formal ou temática directa con outros textos contidos no mesmo volume.

- Textos autónomos integrados en antoloxías ou volumes colectivos xunto con outros textos cos que comparten trazos formais ou temáticos.

- Textos incluídos en obras máis extensas e integrados nelas en maior ou en menor medida.

d) Variedade lingüística

Atendendo á variedade lingüística empregada nos textos podemos establecer os seguintes tipos:

- Galego. Constitúe a categoría non marcada do corpus. Así pois, adscríbense a este tipo os textos escritos en galego que non participan das características de hibridación ou falsificación que definen os seguintes tipos.

- Hibridación galego-castelán. Rexístrase en textos escritos sobre unha base galega fortemente interferida por elementos tomados do castelán.

- Hibridación galego-portugués. Rexístrase en textos que presentan unha base galega cunha significativa presenza de elementos do portugués.

- Galego arcaizante. Corresponden a este tipo os textos pretendidamente medievais que, como parte da súa estratexia falsificatoria, tentan imitar, con desigual pericia, o galego antigo.

- Galego paródico. Adscríbense a este tipo os parlamentos postos en boca de personaxes galegos que, con intención paródica, tratan de remedar o galego seleccionando, acertadamente ou non, trazos estereotipados supostamente representativos.

Non será preciso insistir demasiado na importancia deste parámetro para unha valoración axustada dos datos lingüísticos que presentan os textos. 


\section{A EDICIÓN DE TEXTOS EN GONDOMAR (I). A TRANSCRICIÓN PALEOGRÁFICA ${ }^{2}$}

Tal e como sinalabamos ao comezo, Gondomar ofrece unha multiedición dos textos que forman parte do corpus, e que inclúe, ademais da reprodución facsimilar, unha transcrición paleográfica ou moi conservadora e unha edición interpretativa.

O punto de partida do proceso de edición constitúeo a transcrición dos textos orixinais nun documento xml de acordo co estándar TEI.

\subsection{A cabeceira}

Cada un dos documentos leva unha cabeceira (<teiHeader $>$ ) que contén todas as informacións que permiten identificar o texto electrónico, o seu autor, as diferentes persoas e entidades que tiveron algunha responsabilidade ou intervińeron no proceso de edición, as características da edición, os datos relativos á composición, publicación, transmisión e conservación do texto orixinal, así como a súa caracterización lingüística e tipolóxica.

A cabeceira integra os seguintes elementos básicos:

- $<$ fileDesc $>$, que contén as informacións relativas á identificación, catalogación e caracterización tanto do texto electrónico coma do texto orixinal (autoría, proceso de edición, composición, transmisión, publicación, etc.).

- <encodingDesc $>$, que documenta a relación existente entre o texto electrónico e o texto orixinal.

- <profileDesc>, que informa das características tipolóxicas e lingüísticas do texto.

\subsubsection{Identificación e catalogación do texto}

Os datos relativos á identificación e catalogación do texto documéntanse a través do elemento <fileDesc>, que contén á súa vez os seguintes elementos:

2 O protocolo completo e detallado para a transcrición dos textos pode verse en Álvarez / González Seoane (2017b). 
- <titleStmt>, no que se rexistran os datos identificativos do texto electrónico.

- <publicationStmt $>$, que recolle os datos que identifican a entidade responsable da edición do texto electrónico.

- <seriesStmt>, que identifica a serie ou colección en que se edita o texto electrónico.

- <sourceDesc>, que rexistra os datos identificativos e catalográficos do texto orixinal empregado como base da edición electrónica.

a) Identificación do texto electrónico

Os datos básicos que permiten identificar o texto electrónico documéntanse a través do elemento <titleStmt> que, á súa vez, contén os seguintes elementos:

- <title>, no que se indica o título do texto en versión normalizada.

- <author>, no que se indica o autor do texto, tamén en versión normalizada.

- $<$ respStmt $>$, que permite identificar as distintas persoas que interveńen no proceso de edición do texto electrónico e as tarefas desenvolvidas por cada unha delas. Este elemento contén un ou varios elementos $<$ resp $>$ cun atributo @n, a través do cal se indicará a tarefa realizada ("principal”, para os directores do proxecto; "funder", para a entidade financiadora do proxecto; "edition", para as persoas responsables da edición interpretativa; "transcription", para as persoas responsables da transcrición paleográfica; "annotation”, para as persoas responsables da lematización e anotación...), e, no seu interior, un elemento <name $>$, no que se consigna o nome da persoa ou da entidade responsable de cada tarefa ou función.

b) Identificación da entidade responsable da edición do texto electrónico

O obxectivo desta sección é documentar, a través dun elemento <publicationStmt $>$, os datos editoriais correspondentes ao texto electrónico (entidade ou institución responsable da edición, lugar e data de publicación, dispoñibilidade do texto, etc.). Os elementos previstos nesta sección son os seguintes: 
- <publisher>, que permite rexistrar o nome da institución ou entidade responsable da edición do texto electrónico.

- <pubPlaces, no que se recolle o lugar de publicación do texto electrónico.

- <date>, no que se indica o ano de edición do texto electrónico.

- <availability>, no que se informa sobre a dispoñibilidade e condicións de uso do texto electrónico (restricións, licenzas, etc.).

c) Identificación da serie en que se inscribe o texto electrónico

Esta información introdúcese a través dun elemento <seriesStmt $>$, dentro do cal a indicación da serie ou colección se ofrece mediante un elemento $<$ title>.

d) Identificación e catalogación do texto orixinal

Esta sección ten por obxecto identificar e catalogar, mediante un elemento $<$ sourceDesc $>$, o texto empregado como fonte para a edición do texto electrónico.

Para a definición dos campos que van integrar esta sección debe terse en conta, por unha banda, que os textos que forman parte do corpus poden proceder tanto de fontes impresas coma manuscritas. Por outra banda, en calquera dos dous casos os textos poden constituír un obxecto individualizado (impreso ou manuscrito) ou ben formar parte dun obxecto máis amplo.

\section{Fontes impresas}

Os campos necesarios para a descrición de fontes impresas corresponden aos elementos agrupados baixo a etiqueta <biblStruct $>$, un dos elementos posibles dentro da etiqueta $<$ sourceDesc $>$.

Débese ter en conta que a maior parte dos textos do corpus procedentes de fontes impresas son pezas, fragmentos ou partes contidas en obras máis amplas. En consecuencia, é necesario distinguir, por unha banda, unha serie de campos referidos ao texto propiamente dito, que se agrupan baixo un elemento $<$ analytic>, e, por outra, unha serie de campos que se refiren á obra ou volume 
en que está contido o texto - ou ben ao texto cando este constitúe unha obra independente-, que se agrupan baixo un elemento <monogr $>$.

Dentro do elemento <analytic>, onde se describe o texto propiamente dito, poden inserirse os seguintes elementos:

- <author>, no que se indica o autor do texto tal e como figura mencionado nel.

- <title>, no que se indica o título orixinal do texto na forma en que figura neste.

- <date>, que se cobre só cando o texto leva unha data diferente da data de edición da obra que o contén.

- <textLang>, no que indica a lingua ou linguas en que está escrito o texto.

A información sobre a obra en que se inscribe o texto (ou sobre o texto, cando este constitúe unha obra independente) rexístrase, como xa queda dito, mediante un elemento <monogr>, que contén á súa vez os seguintes elementos:

- <author>, no que se indica o nome do autor da obra tal e como figura nela.

- <editor>, no que se indica, no caso de antoloxías e obras de autor múltiplo, o nome da persoa que actúa como editor ou compilador.

- < title>, no que se consigna o título do volume ou da publicación periódica de que forma parte o texto.

- <imprint $>$, no que se indican os datos relativos á publicación do texto. Para iso, no seu interior insírense os elementos < pubPlace $>$, para indicar o lugar de publicación; <publisher $>$, para rexistrar o nome da editora ou imprenta, e $<$ date $>$, para consignar o ano de publicación da obra.

- <extent>, no que se indica o número de páxinas que compoñen a obra.

- <textLang>, no que se indica a lingua ou linguas empregadas na obra.

- <biblScope>, a través do cal se indica en que lugar da obra (volume, número, páxinas) está localizado o texto. 


\section{Fontes manuscritas}

Os elementos necesarios para a descrición de fontes manuscritas corresponden ás informacións agrupadas baixo o elemento $<\mathrm{msDesc}>$, un dos elementos posibles dentro de $<$ sourceDesc $>$.

O elemento $<\mathrm{msDesc}>$ pode, á súa vez, conter no seu interior os seguintes elementos:

- $<$ msIdentifier $>$, que contén todas as informacións necesarias para identificar e localizar o manuscrito correspondente ao texto.

- $<$ msContents $>$, que recolle a descrición da parte do manuscrito que contén o texto.

- <physDesc $>$, que permite realizar unha descrición completa das características físicas do manuscrito.

- $<$ history $>$, no que se recolle a información sobre a historia do manuscrito.

No interior do elemento <msIdentifier> intégrase unha serie de elementos que teńen por obxecto identificar e localizar o manuscrito correspondente ao texto (ou en que figura o texto):

- <institution>, no que se recolle o nome da institución en que se encontra depositado o manuscrito.

- <repository>, no que se recolle o nome da biblioteca ou arquivo no que se conserva o manuscrito.

- <settlement>, no que se rexistra o nome da cidade en que se encontra a dita institución.

- <country>, no que se rexistra o nome do país correspondente.

- <collection>, no que se indica o nome da colección de que forma parte o manuscrito.

- $<$ idno $>$, no que se indica a signatura do manuscrito.

- <altIdentifier $>$, que pode conter no seu interior os elementos sinalados anteriormente, e que permite documentar o paso do manuscrito por outras institucións, así como sinaturas que tivo anteriormente dentro da mesma institución. 
- $<$ msName $>$, no que se consigna o nome con que é coñecido o manuscrito que contén o texto.

No interior do elemento <msContents> intégrase unha serie de elementos que teñen por obxecto describir o contido do manuscrito e, en particular, a parte do manuscrito que contén o texto (tanto se manuscrito e texto coinciden coma se non):

- <textLang >, no que se indica a lingua ou linguas empregadas no conxunto do manuscrito.

- <msItem>, que permite rexistrar as informacións relativas á parte do manuscrito que contén o texto. Para iso, no seu interior inclúense os seguintes elementos:

o <author>, no que se consigna o nome do autor ou autora do texto na súa forma orixinal, non normalizada.

o < title>, no que se consigna o título do texto na súa forma orixinal.

o < respStmt $>$, no que se consignan outras mencións de responsabilidade. Con este fin, emprégase o atributo @n para indicar a función realizada ("edition", "transcription", "translation", etc.) e o elemento <name> para documentar o nome da persoa responsable.

o <locus $>$, no que se indica a localización do texto dentro do manuscrito.

$0<$ textLang $>$, no que se indica a lingua ou linguas empregadas no texto.

No interior do elemento <physDesc $>$ intégrase unha serie de elementos que teñen por obxecto describir as características físicas do manuscrito:

- <objectDesc>, que contén á súa vez unha serie de elementos destinados a describir as características do manuscrito:

o <supportDesc>, no que se recollen as informacións relativas aos aspectos materiais do manuscrito, da súa constitución, do seu estado de conservación, etc.

- <support>, para indicar o tipo de soporte (papel, pergamiño...).

- <extent>, para indicar o número de páxinas. 
- <dimensions> (cun atributo @unit, no que se indica a unidade de medida e uns elementos $<$ height $>$ e $<$ width $>$ ), para indicar as medidas do manuscrito.

- <collation>, para indicar como está constituído fisicamente o manuscrito.

- <foliation>, para indicar o sistema empregado para a numeración das páxinas do manuscrito.

- <condition>, para dar conta do estado de conservación do manuscrito.

o <layoutDesc>, no que se ofrecen detalles sobre a distribución do texto en páxina.

- <handDesc>, no que se dá conta das mans que intervińeron no manuscrito.

- < bindingDesc >, no que se indica o tipo de encadernación do manuscrito.

Finalmente, no interior do elemento <history> intégrase unha serie de elementos que teńen por obxecto estruturar a información sobre a historia do manuscrito:

- <origin>, no que se indica, se é posible, cando, onde e en que circunstancias foi redactado o manuscrito.

- <provenance>, no que se documenta, se é posible, o percorrido do manuscrito desde a súa redacción ata a súa adquisición polo seu propietario actual.

- <acquisition>, no que se indica, se é posible, a fórmula ou procedemento polo que o manuscrito chegou ás mans do propietario actual.

\subsubsection{Relación entre texto electrónico e texto orixinal}

Esta información consígnase a través dun elemento <encodingDesc $>$, no que se indica de xeito sumario o tipo de edición realizada e as modificacións introducidas na edición electrónica con respecto ao texto orixinal. 


\subsubsection{Clasificación lingüistica e tipolóxica do texto}

Para a clasificación lingüística e tipolóxica do texto emprégase un elemento <profileDesc>, que á súa vez contén no seu interior os seguintes elementos:

- <creation>, que contén no seu interior un elemento <date $>$ no que se indica o ano en que se quere datar o texto. Este elemento será empregado logo como parámetro nas buscas que se realicen sobre o corpus.

- $<$ textClass $>$, que contén no seu interior un elemento <keywords $>$. No seu interior consígnanse, a través do elemento $<$ term $>$, as características tipolóxicas do texto de acordo cos seguintes parámetros de clasificación:

o @subcat="source type", que permite indicar se o texto é impreso ou manuscrito.

o@subcat="text type", que permite clasificar o texto como literario (para o que se prevén os seguintes tipos: poesía culta, poesía popular, poesía cancioneiril, vilancico, texto dramático ou dialogado, texto en prosa) ou como non literario (para o que se prevén os seguintes tipos: prosa documental, correspondencia privada, texto historiográfico, refráns e proverbios, e glosas e anotacións).

o @subcat="circulation", que permite clasificar o texto como privado, semipúblico ou público.

o @subcat="autonomy", que permite clasificar o texto como autónomo, compilado ou non autónomo.

- <langUsage>, cun elemento <language> no seu interior, que permite identificar a lingua, variedade ou rexistro en que está escrito o texto. Sen prexuízo de que sexa necesario ampliar esta clasificación, prevense a priori as seguintes variedades: galego, hibridación galego-castelán, hibridación galego-portugués, galego arcaizante, galego paródico.

\subsection{A transcrición do texto}

Os criterios de transcrición adoptados teñen por obxecto fornecer un primeiro nivel de edición que reproduza o texto orixinal coa máxima fidelidade posible. Por esta razón, óptase por respectar as grafías empregadas (agás no caso de gra- 
femas desusados, coma o $\int$, que se resolve en $s$ ), a acentuación, a puntuación, a separación de palabras, as abreviaturas, os saltos de liña, columna e páxina, etc. Ademais, sinálanse as lagoas, riscaduras, emendas e dificultades de lectura apreciadas no texto orixinal, que se visualizan na aplicación de lectura mediante o contraste de cor.

\subsubsection{Elementos estruturais básicos}

O texto propiamente dito queda demarcado dentro do documento xml por un elemento $<$ text $>$, que contén un elemento obrigatorio $<$ body $>$. Este pode ir precedido dun elemento opcional $<$ front $>$ e seguido dun elemento $<$ back $>$, tamén opcional:

- $\quad<$ body > contén o texto propiamente dito.

- <front> emprégase para demarcar mencións que preceden o texto e que non forman parte del, como por exemplo, un título ou a indicación do tipo de estrofa de que se trata, o nome do autor, unha dedicatoria, etc.

- <back> emprégase para demarcar mencións de características análogas ás mencionadas para $<$ front $>$ que aparecen a continuación do texto propiamente dito (por exemplo, nome do autor, lugar de redacción do texto, data...).

O elemento <front> pode conter, á súa vez, unha ou varias seccións, que se marcan empregando o elemento $<$ div $>$. Á súa vez, $<$ div $>$ pode conter un ou varios dos seguintes elementos, entre outros:

- $<$ head > para a mención do título e autor do texto.

- <epigraph> para as citas introdutorias, dedicatorias, etc.

- <set> para a descrición da escena ou para a localización espacial ou temporal da acción (no caso das pezas teatrais ou parateatrais).

- <castList> para introducir a relación de personaxes (e eventualmente o reparto de actores) no caso de pezas teatrais ou parateatrais. Este elemento pode incluír, á súa vez, un elemento <head> para introducir a fórmula empregada para encabezar esta sección no texto orixinal e un elemento $<$ castItem $>$ para cada personaxe. 
O elemento $<$ body $>$ contén un ou varios elementos $<$ div $>$, que corresponden ás divisións ou seccións que pode presentar o corpo do texto. Emprégase este elemento para diferenciar, por exemplo, partes do texto separadas por epígrafes, espazos en branco, sinais divisorios, etc.

Nos textos en prosa e verso, cada elemento < div> pode conter un ou varios dos seguintes elementos:

- $\quad<\mathrm{p}>$ para parágrafos en prosa.

- $<\mathrm{lg}>$ para grupos de versos que funcionan como unha unidade formal (por exemplo, estrofas, retrousos, etc.). Os distintos versos contidos dentro dun elemento $<\mathrm{lg}>$ están demarcados polo elemento $<\mathrm{l}>$.

Nos textos teatrais ou parateatrais, as diferentes unidades estruturais márcanse mediante cadanseu elemento <div>, que, de ser o caso, vai acompańado dun atributo @type no que se indica o tipo de unidade de que se trate ("act", "scene”...) e dun atributo@n no que se indica o número que corresponda.

Nos textos dramáticos e, en xeral, nos textos dialogados, cada unha das intervencións vai inserida dentro dun elemento $<$ sp $>$, acompañado dun atributo @who, no que se especifica o nome ou a identidade do personaxe que fala. Esta identificación realízase a través dunha forma normalizada e, por tanto, non necesariamente coincidente coa que figura no texto orixinal introducindo cada parlamento. Este elemento <sp > pode, á súa vez, conter os seguintes elementos:

- <speaker> para a indicación do nome ou mención tal e como figura no texto orixinal.

- $\quad$ p $>$ para os parlamentos en prosa.

- $\quad$ l> para os parlamentos en verso.

- $<\mathrm{lg}>$ para poemas, cancións ou fragmentos en verso inseridos no texto e que presentan entidade propia. Este elemento contén no seu interior un elemento $<$ l $>$ para cada verso. 
Nos textos teatrais e parateatrais, as indicacións escénicas (decorados, accións que realizan os personaxes, entradas e saídas de escena, etc.) márcanse mediante o elemento <stage $>$.

Finalmente, o elemento <back> pode, á súa vez, conter unha ou varias seccións, que se marcan mediante o elemento $<$ div $>$. Este elemento pode incluír no seu interior outros elementos, como por exemplo:

- <trailer> para indicacións de final de texto, colofóns, etc.

\subsubsection{Saltos de páxina, columna e liña}

a) Saltos de páxina

O comezo dunha nova páxina ou folio márcase cun elemento $<\mathrm{pb} />$. Este elemento vai acompańado de dous atributos:

- @n, que indica o número de páxina ou folio.

- @facs, que permite vincular as páxinas do texto cos arquivos que conteñen as reproducións facsimilares correspondentes.

b) Saltos de columna

Os saltos de columna márcanse inserindo no lugar correspondente un elemento $<\mathrm{cb} />$, seguido dun atributo @n que indica o número de columna. Para este fin empréganse as letras "a" e "b" (e "c"... no caso improbable de que sexan máis de dúas).

c) Saltos de liña

Nos textos en prosa os saltos de liña márcanse inserindo no lugar correspondente un elemento $<\mathrm{lb} />$, seguido dun atributo @n que indica o número de lińa.

Para a indicación das lińas nos textos en verso emprégase, segundo queda dito, un elemento $<\mathrm{l}>$. 
Nos casos en que o salto de lińa cadre no interior dunha palabra, o elemento insírese no lugar correspondente (con eliminación do guión de final de lińa).

\subsubsection{Riscaduras e supresións existentes no texto orixinal}

Os fragmentos que no texto orixinal aparecen riscados mediante un trazo ou un borrancho márcanse mediante un elemento <del> seguido dun atributo @type, no que se indica "overstrike".

No caso de que o texto riscado sexa lexible, esta circunstancia sinálase conforme se indica a seguir:

$<$ del type="overstrike" $>$ ti $</$ del $>$ non me has ti de aloumiñar

Se, pola contra, o texto riscado é ilexible, emprégase un elemento baleiro con indicación, se é posible, do número de caracteres riscados (mediante os atributos @quantity e @unit):

$<$ del type="overstrike" quantity="4" unit="character"/>

\subsubsection{Correccións e adicións existentes no texto orixinal}

Para indicar a introdución dun ou varios caracteres que substitúen outros que figuraban no texto emprégase o elemento $<$ subst $>$.

- Dentro do elemento <subst> o fragmento suprimido márcase mediante un elemento <del>, seguido dun atributo @type no que se indica o procedemento empregado para a corrección ("overwrite" para correccións mediante sobrescritura, "overstrike" para correccións mediante riscaduras e borranchos...).

- $\mathrm{O}$ texto engadido indícase mediante un elemento <add>, seguido dun atributo @place, no que se especifica o lugar en que se insire o texto engadido: "above" (sobre a liña), "below" (baixo a lińa), "inline" (na lińa), "margin" (na marxe esquerda ou dereita), "top" (na marxe superior da páxina), "bottom" (na marxe inferior da páxina), "overleaf” (no reverso da páxina). 
A seguir, ofrécense algúns exemplos de intervención.

\section{Texto sobrescrito}

Trátase de casos en que a corrección se realizou no texto orixinal escribindo un ou varios caracteres directamente enriba dos que se pretendía substituír ou corrixir:

é $<$ subst $><$ del type $=$ "overwrite" $>$ b $</$ del $><$ add $>\mathrm{v}</$ add $></$ subst $>$ òs para cubizár

Se o texto substituído non resultase lexible, emprégase a etiqueta baleira correspondente, pero, sempre que resulte posible, con indicación do número de caracteres eliminados:

é $<$ subst $><$ del type="overwrite" quantity="1" unit="character" $/><$ add $>\mathrm{v}</$ add $></$ subst $>$ os.

\section{Corrección na interliña}

Trátase de casos en que a corrección se realizou no documento orixinal riscando un ou varios caracteres e inserindo outros na interliña (superior ou inferior):

Se $<$ subst $><$ del type = "overstrike" $>$ stanno $</$ del $>\quad<$ add place="above" $>$ d'esta $</$ add $>$ $<$ /subst $>$ non dòu de costas

Tamén neste caso, se o texto riscado non resultase lexible, emprégase a etiqueta baleira con indicación do número de caracteres riscados:

Se $<$ subst $><$ del type="overstrike" quantity="6" unit="character"/ $><$ add place="above" $>$ d'esta $</$ add $></$ subst $>$ non dòu de costas

\section{Inserción de texto na liña}

Neste caso, a corrección realizouse no orixinal mediante a inserción de texto na propia lińa:

non me has $<$ add place= "inline" $>$ ti $</$ add $>$ de aloumiñar? 
Se ademais da inserción no orixinal hai algún elemento riscado, este indícase mediante un elemento <del>, conforme se indica no apartado 2.2.3.:

$<$ del type="overstrike" $>$ ti $</$ del $>$ non me has $<$ add place="inline" $>$ ti $</$ add $>$ de aloumiñar?

\section{Inserción de texto na marxe}

Para a inserción de texto na marxe esquerda, dereita, superior ou inferior da páxina, ou no reverso emprégase tamén o elemento <add> co atributo @place, no que se indica se o texto foi inserido na marxe ("margin"), na parte superior da páxina ("top"), na parte interior da páxina ("bottom”) ou no reverso (“overleaf”).

\subsubsection{Espazos en branco no texto orixinal}

Se o texto presenta un espazo en branco claramente perceptible (como por exemplo o deixado adrede para ser cuberto logo cun dato que se descońece no momento da redacción), emprégase o elemento <space/>, cos atributos @quantity e @unit:

e viron un <space quantity=" 4 " unit="character"/> no ceo

\subsubsection{Deterioración do soporte}

Emprégase o elemento <damage > para dar conta daqueles casos en que o soporte material do documento presenta unha área deteriorada, por exemplo, por rotura, queimadura, acción de insectos ou roedores, humidade, etc., de tal xeito que falta unha parte do texto ou ben este resulta total ou parcialmente ilexible. Este elemento pode ir acompańado dos seguintes atributos:

- @agent, para indicar a causa da deterioración (“fire”, "smoke”, “mildew”...)

- @unit, para o tipo de unidade ("character", "word”, "line”...)

- @quantity, para o número de unidades afectadas (“1”, “2”, “3”...)

Así, se, por exemplo, como consecuencia da acción do lume nun documento falta a parte superior dunha páxina, correspondente aproximadamente ás tres 
primeiras liñas, indícase esta circunstancia mediante un elemento baleiro $<$ damage/ $>$ :

$<$ damage agent="fire" unit="line" quantity="3"/>

Se por esta mesma causa falta a zona esquerda dunha páxina, indícase ao comezo de cada lińa o número aproximado de caracteres que faltan:

$<$ damage agent="fire" unit="character" quantity="8"/>

Cando dentro dunha área deteriorada hai palabras ou caracteres que se poden ler emprégase un elemento <damage > para delimitar a área. No seu interior, os fragmentos non recuperables indícanse mediante o elemento <gap $>$ (cos atributos@quantity e @unit). Os fragmentos lexibles indícanse sen máis, ou, no caso de que a lectura sexa insegura, demarcados por un elemento <unclear $>$ :

$<$ damage agent="fire" $>$ gap unit="characters" quantity=" 4 " $/><$ unclear $>$ eiro $</$ unclear $>$ $</$ damage $>$

Cando todo ou parte do texto que falta nunha área deteriorada é reconstruíble de xeito hipotético ou conxectural, este indícase mediante un elemento $<$ supplied >:

$<$ damage agent="fire" $><$ supplied $>$ querido $</$ supplied $><$ damage $>$

\subsubsection{Dificultade de lectura e ilexibilidade do texto}

Cando o texto presenta nalgún punto dificultades de lectura, emprégase o elemento <unclear $>$ (non demarcado por <damage $>$ ) para indicar o fragmento sobre o que editor ten dúbidas:

$<$ unclear $>$ verda $<$ /unclear $>$ deiro 


\subsubsection{Notas ou glosas á marxe}

Cando o texto presenta glosas ou notas explicativas á marxe, estas indícanse co elemento <textnote>, que se insire no lugar do texto a que corresponda a nota (a continuación da palabra ou palabras glosadas, na fin da lińa ou do parágrafo, etc.).

O elemento <textnote> complétase cos atributos @type (para o tipo de información introducida: "gloss"...) e @place (para o lugar en que figura a nota no texto orixinal: "margin", "bottom”...).

$<\mathrm{l}>$ Embejando o Indo, è o Ganjes</l>

$<\mathrm{l}>$ Os nosos Sar, è Sarela <textnote type="gloss" place="margin" $><$ foreign xml:lang $=$ "es" $>$ Rios de Santiago $</$ foreign $>.</$ textnote $>.</ l>$

\subsubsection{Cambios de man}

Se nun texto manuscrito aparecen varias mans, os sucesivos cambios indícanse mediante un elemento < handShift/> acompañado dun atributo @new, no que se indica a man de que se trate:

$<$ handShift new="\#h1"/>

Cómpre lembrar que as diferentes mans deben quedar identificadas na cabeceira dentro do elemento $<$ handNote $>$.

\subsubsection{Cambios de lingua}

$\mathrm{Na}$ cabeceira dos textos hai un elemento que permite identificar a lingua principal do texto ("gl") e, ao mesmo tempo, precisar a variedade empregada (galego, galego paródico, galego arcaizante, hibridación galego-castelán, hibridación galego-portugués).

Cando nun texto do corpus aparecen fragmentos escritos noutra lingua, esta circunstancia indícase mediante un elemento <foreign $>$ acompañado dun atributo @xml:lang, mediante o que se especifica a lingua de que se trate, sempre de acordo co sistema de abreviaturas normalizado (cfr. http://www.iana.org/assig- 
nments/language-subtag-registry/language-subtag-registry): "es" (español), "la" (latín), "pt" (portugués), etc.

$<$ foreign xml:lang="es" $>$ SONETO GALLEGO de el Liçenciado Pedro Bazquez de Neyra $</$ foreign $><$ lb/ $><$ foreign xml:lang="la" $>$ RESPICE FINEM $</$ foreign $>$

\subsubsection{Imaxes}

Cando no texto aparece inserido un debuxo ou imaxe sinálase a súa presenza mediante o elemento <figure>, que pode conter, á súa vez, outros elementos, coma no exemplo que segue, en que temos un debuxo (indicado mediante un elemento $<$ graphic>, acompañado dun atributo @url onde se indica o arquivo que o contén) precedido dunha referencia bíblica a xeito de título ou cabeceira (marcada mediante un elemento $<$ head $>$ ) e seguido duns versos (indicados mediante un elemento $\langle\lg >$ ):

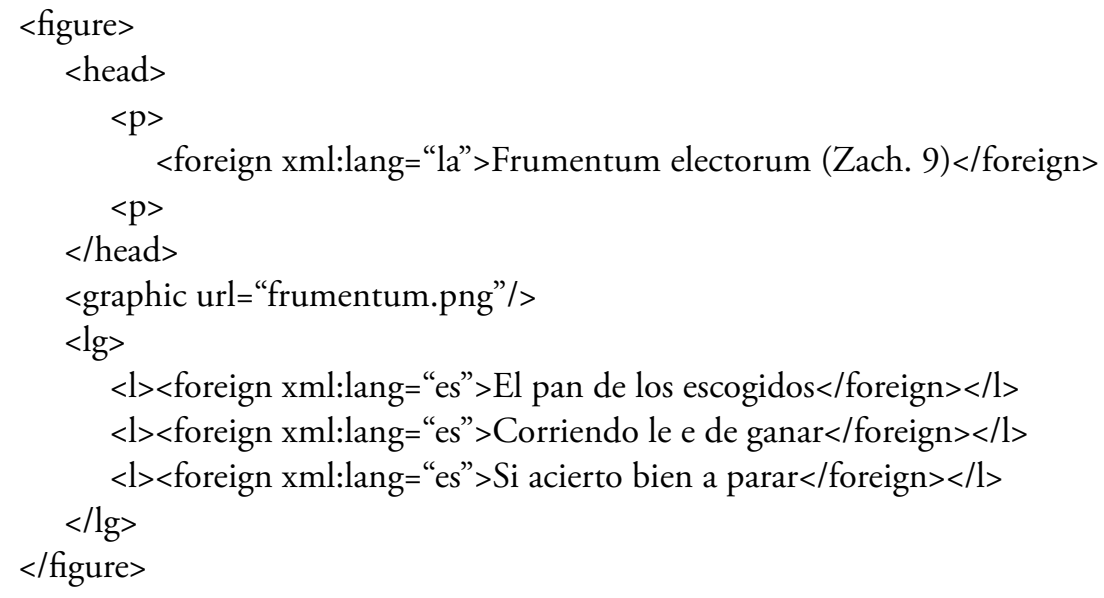




\section{A EDICIÓN DE TEXTOS EN GONDOMAR(II). A EDICIÓN INTERPRETATIVA ${ }^{3}$}

Tomando como punto de partida a transcrición paleográfica, abórdase a elaboración dun segundo nivel de edición, correspondente á edición interpretativa, que ten por obxecto facilitarlle ao lector moderno unha lectura e interpretación do texto acorde co que, segundo o xuízo do editor ou editora, sería a vontade autorial. Ao tempo, a edición interpretativa aspira a facilitar o traballo de recuperación de datos a partir do corpus, para o que resulta imprescindible reducir no posible a heterografía e outras formas de variación non relevantes do punto de vista lingüístico. Por iso, dentro do respecto básico ao teor do orixinal, na edición interpretativa intervense de forma fundamental, como veremos a seguir, en aspectos de carácter formal.

Todo o proceso de edición dos textos, así como a súa anotación morfosintáctica e a súa lematización, realízanse a través de TEITOK, unha plataforma desenvolvida por Maarten Janssen que permite a multiedición, anotación, lematización e visualización de textos en formato xml e, ademais, a súa compilación e explotación como corpus lingüístico (cfr. Janssen 2016 e a contribución de Janssen / Vaamonde neste mesmo volume). As modificacións e variantes correspondentes á edición interpretativa introdúcense a través dun formulario dispoñible na plataforma. Este formulario permite tamén introducir para cada token a forma estándar correspondente. Isto posibilita que, logo, na ferramenta de visualización dos textos sexa posible alternar entre os diferentes niveis de edición (transcrición, edición interpretativa, edición modernizada). Polo demais, a introdución da forma estándar permite a lematización e anotación automática dos textos. En todos os casos, as variantes introducidas a través do formulario insírense de xeito automático no documento xml como atributos do token de que se trate en cada caso.

3 Unha versión máis detallada dos criterios para a elaboración da edición interpretativa poden verse en Álvarez / González Seoane (2017c). 


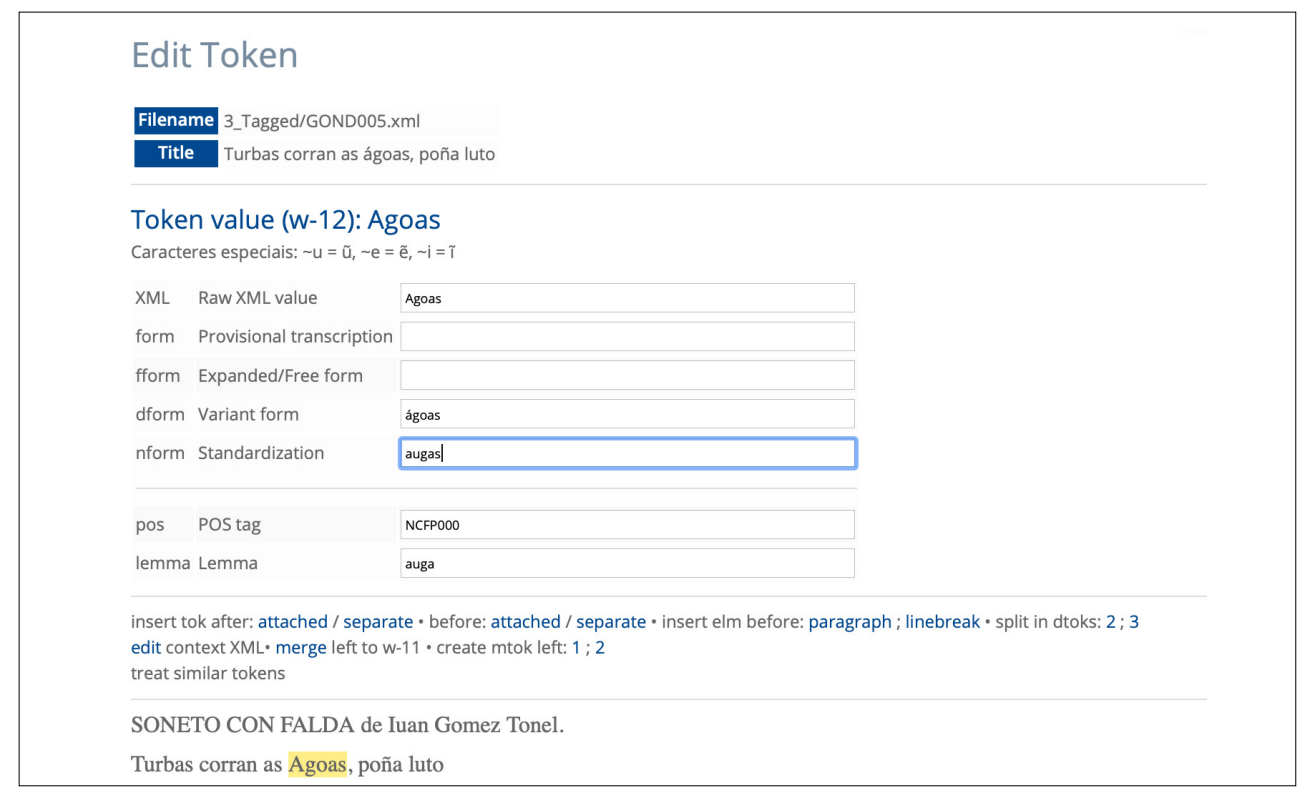

Figura 1. Formulario de edición do token en TEITOK

Segundo queda dito, a edición interpretativa parte da transcrición paleográfica, da que se toman as que se consideran as lecturas definitivas do texto, eliminando por tanto as indicacións de emendas, insercións, riscaduras, etc. Do mesmo xeito, os treitos ilexibles e as lagoas márcanse no texto simplemente cun signo convencional ([...]), mais sen indicación da súa extensión. Por outra banda, resáltanse cun código de cor as lecturas hipotéticas ou conxecturais e desenvólvense as abreviaturas. Sexa como for, dado que a aplicación de lectura dos textos permite alternar en todo momento entre os diferentes niveis de edición, sempre resulta posible recuperar ou comprobar a información que a edición interpretativa non ofrece.

Polo demais, na edición interpretativa a intervención dos editores queda limitada ao plano gráfico, e máis en concreto aos seguintes aspectos:

- Regularízase a separación de palabras, seguindo de maneira xeral o criterio do galego moderno (ou, cando isto non é aplicable, o do portugués):

da quel gran Cavaleyro $\rightarrow$ daquel gran cabaleiro 
- Regularízanse, conforme ao criterio dos editores, formatos de letra (cursivas, versaletas, etc.). Así, por exemplo, adóptase a cursiva para transcribir os retrousos ou as coplas que dan pé ás glosas.

- Regularízase o emprego dos signos de puntuación:

o Suprímense ou engádense signos de puntuación consonte a interpretación que os editores entenden que se lle debe dar ao texto:

Mandan, que se han de compòr / Vinte copras $\rightarrow$ Mandan que se han de compor / vinte copras

o No caso dos signos de admiración e interrogación, procúrase utilizar, sempre que resulta posible, o inicial e o final:

sopòn a vn luceyro sò: / Cinco à vn, è ser Galegos? $\rightarrow$ s'opón a un luceiro só: / ¡cinco a un e ser galegos?

- Utilízase a raia para demarcar os incisos:

Ou luceyros (diz à Estrela, Facendo das luzes voz) $\rightarrow$ Ou luceiros — diz à Estrela, facendo das luzes voz-,

o Márcase con raia o estilo directo cando ten forma de diálogo. Cando, pola contra, forma parte do mesmo parágrafo, enmárcase entre comiñas angulares:

—Ou luceiros — diz a estrela, / facendo das luces voz—, / miraime, miraime ben, / verès quen vos arrolou (...).

unha táboa de pedra con letras que rezaban: «Aiquí será poboada la gran cibdad».

o Nos diálogos, utilízanse comiñas de seguimento cando o parlamento dun personaxe se estende por máis dun parágrafo ou estrofa:

—Ou, luceiros — diz a estrela,

facendo das luces voz-,

miraime, miraime ben,

verés quen vos arrolou. 


$$
\begin{aligned}
& \text { „Eu vos faixei coma nenos; } \\
& \text { ¿querés qu’eu non sexa mor? } \\
& \text { Reparai qu’o voso lume } \\
& \text { ós meus peitos se criou. }
\end{aligned}
$$

- Regularízase, de acordo co uso moderno, o emprego de maiúsculas e minúsculas. En particular, no caso dos textos en verso evítase o uso de maiúscula para marcar o comezo do verso, agás que o seu uso obedeza a algunha outra xustificación.

- Regularízase á moderna, con carácter xeral, o emprego do acento gráfico, tanto cando este se usa para marcar a intensidade coma cando ten función diacrítica.

- A contracción da preposición $a$ e o artigo masculino (representada nos textos como $<o, \grave{o}, o ́, h o \ldots>$ ) regularízase en $o ́($ e non en $a o$ ):

Obrigada ò seu respeyto $\rightarrow$ obrigada ó seu respeito

o Nos casos de dúbida, óptase pola interpretación máis congruente desde o punto de vista dos editores ou, en todo caso, pola máis conservadora: Fonseca ò mundo pasmou $\rightarrow$ Fonseca o mundo pasmou

- Regularízase, conforme o uso moderno, o emprego da diérese: antiguidade $\rightarrow$ antigüidade

- Utilízase o apóstrofo para marcar elisións fonéticas de diverso tipo:

- Nas elisións vocálicas, úsase tanto se así consta no orixinal coma no caso de ser necesario para marcar a separación de palabras: un par d'anos $\rightarrow$ un par d'anos.

Ou so seu respeyto foi $\rightarrow$ ou s'o seu respeito foi

- Nas amálgamas do tipo prautra, pronha, utilízase para separar o segmento gráfico que corresponde ao nexo, sen vogal final, do que corresponde ao determinante, coa vogal inicial modificada:

pronha vida $\rightarrow$ pr'onha vida 
- Emprégase para separar o segmento consonántico e o vocálico en casos de crase entre a vogal final dunha forma verbal e a inicial do clítico:

Castigos Noso Señor $\rightarrow$ Castig'os Noso Señor

bejos calados $\rightarrow$ vex'os calados

- Nos casos en que a contracción comporta a modificación gráfica dalgún dos elementos implicados, reponse a grafía correspondente:

dixo co vira $\rightarrow$ dixo qu'o vira

- Nas palabras rematadas en -ade, -ede, -ude e as súas variantes truncadas, mantense a grafía do texto cando a variante empregada no texto remata en vogal tónica ou en -de; mantense tamén cando o texto presenta unha variante en $-d$ seguida de consoante ou pausa; pola contra, emprégase apóstrofo cando o texto presenta unha variante en $-d$ seguida de vogal:

Mais tamen è gran verdade / Que non tuvo à terra Pay $\rightarrow$ mais tamén é gran verdade / que non tuvo a terra pai

E verda que foi seu Fillo $\rightarrow$ É verdá que foi seu fillo

se esta cidad vive $\rightarrow$ se esta cidad vive

que cô sua autoridad ajudase $\rightarrow$ que con súa autoridad'axudase

- Nas formas apocopadas san/sant, gran/grand aplícase o mesmo criterio indicado na alínea anterior:

Do gran Iulio $\rightarrow$ do gran Xulio

grand prez $\rightarrow$ grand prez

Do grand home $\rightarrow$ do grand'home

- Emprégase para separar a variante $n(0)$ do adverbio de negación ante palabra iniciada por vogal:

ne verdade $\rightarrow$ n'é verdade

no è razón $\rightarrow$ no'é razón

Que no ay no descuberto $\rightarrow$ que no'hai (= non hai) no descuberto

no ostante $\rightarrow$ no'ostante

nostante $\rightarrow$ n'ostante 
o No caso das contraccións con clíticos do acusativo de terceira persoa procédese como se indica a seguir:

no vin $\rightarrow$ n'o vin

noo vin $\rightarrow$ no'o vin

noa via $\rightarrow$ no’a vía

navia $\rightarrow$ n’a vía

o Non se marcan con apóstrofo as reducións grafemáticas que se editan restablecendo os grafemas correspondentes (fundamentalmente, entre sibilantes e/ou róticos):

da suas letras $\rightarrow$ das suas letras

- Regularízase conforme o uso moderno o emprego do guión de enlace. Utilízase ademais nestoutros casos, non previstos na norma actual:

- Para marcar o linde nos casos de contracción do adverbio non cos clíticos de primeira persoa de plural e de terceira de singular ou plural, con redución ou amálgama da nasal final, de acordo coa seguinte táboa:

\begin{tabular}{lll}
\cline { 2 - 3 } non + P3 ou P6 & \multicolumn{1}{c}{ Orixinal } & \multicolumn{1}{c}{ Ed. interpretativa } \\
\cline { 2 - 3 } & non-o, non-a, non-os, non-as & non-o, non-a, non-os, non-as \\
\cline { 2 - 3 } & nono, nona, nonos, nonas & non-o, non-a, non-os, non-as \\
\hline nonno, nonna, nonnos, nonnas & non-no, non-na, non-nos, non-nas \\
\hline non + P4 & nonos & no-nos \\
\cline { 2 - 3 } & nonnos & non nos \\
\hline
\end{tabular}

o Para marcar a redución fonética do adverbio non ante nasal ou noutros contextos:

No mo dà ò corazon $\rightarrow$ no-mo dá o corazón

o Para marcar a epéntese de [j]:

a yalma $\rightarrow$ a i-alma

o Para marcar a separación de pronomes mesoclíticos:

dicir-vos-ei 
o Non se usa guión, en cambio, como marca de separación entre a variante $<\mathrm{i}>$ da conxunción copulativa e a vogal coa que forma sílaba:

yeu $\rightarrow \mathrm{i}$ eu

ela ieles $\rightarrow$ ela i eles

- Mantéñense con carácter xeral as contraccións que presentan os textos orixinais, e, cando procede, márcanse cun acento diacrítico seguindo os criterios normativos que rexen o uso do acento gráfico no galego moderno:

\begin{tabular}{lll} 
& \multicolumn{1}{c}{ Orixinal } & \multicolumn{1}{c}{ Edición interpretativa } \\
\hline a + o, os & ao(s), â o(s), à o(s)... & ao, aos \\
\hline pra + o, a, os, as & $\begin{array}{l}\text { pro(s) / pra(s), pró(s) / prá(s), pró, prá, prós, prás } \\
\text { prô(s) / prâ(s)... }\end{array}$ \\
\hline ca+o, a os, as & $\begin{array}{l}\text { có(s) / cá(s), cò(s) / cà(s), co(s) / có, cá, cós, cás } \\
\text { ca(s)... }\end{array}$ \\
\hline $\begin{array}{l}\text { con + el, ela, eles, } \\
\text { elas }\end{array}$ & $\begin{array}{l}\text { coel(es) /coela(s), co-el(es) / co- coel, coela, coeles, coelas } \\
\text { ela(s), co el(es) / co ela(s)... }\end{array}$ \\
\hline
\end{tabular}

o Gráfanse conforme o uso moderno aquelas secuencias en que a contracción non repercute na contaxe de sílabas nin noutros aspectos da versificación:

Todos os de este destreyto $\rightarrow$ todos os deste destreito

o Pola contra, cando isto non ocorre, os membros da secuencia mantéñense separados:

Si o nacer con vnha Estrela $\rightarrow$ Si ó nacer con unha estrela

- Regularízase, conforme o uso moderno, o emprego de grafemas e dígrafos. O obxectivo é eliminar na edición interpretativa a variación gráfica que carece de relevancia desde o punto de vista fonético, sempre considerando o estadio lingüístico do momento de produción dos textos. A seguir móstranse as intervencións máis frecuentes: 


\begin{tabular}{|c|c|c|}
\hline Grafía orixinal & Ed. interpretativa & Exemplos \\
\hline$<c ̧, z>+e, i$ & $\mathrm{ce}, \mathrm{ci}$ & $\begin{array}{l}\text { Porçia } \rightarrow \text { Porcia } \\
\text { he dezernos, que rezemos } \rightarrow \text { é decernos } \\
\text { que recemos }\end{array}$ \\
\hline$<q u>(/ k w /)$ & $\mathrm{cu}$ & $\begin{array}{l}\text { questios } \rightarrow \text { cuestiós } \\
\text { quando } \rightarrow \text { cuando }\end{array}$ \\
\hline$<c ̧>+a, o, u$ & za, zo, zu & obrigaçon $\rightarrow$ obrigazón \\
\hline$<\mathrm{g}>+\mathrm{e}, \mathrm{i}(/ \mathrm{g} /)$ & gue, gui & gerra $\rightarrow$ guerra \\
\hline$<g, j, x>/ g /$ & $x$ & fayja $\rightarrow$ faixa \\
\hline$<\mathrm{h}>$ & $\mathrm{h} / \varnothing$ & $\begin{array}{l}\text { ay } \rightarrow \text { hai } \\
\text { he } \rightarrow \text { e, he } \rightarrow \text { é }\end{array}$ \\
\hline$<\mathrm{th}>(/ \mathrm{t} /),<\mathrm{ch}>(/ \mathrm{k} /)$ & $\mathrm{t}, \mathrm{c}$ & $\begin{array}{l}\text { theologia } \rightarrow \text { teoloxía } \\
\text { charta } \rightarrow \text { carta }\end{array}$ \\
\hline$<\mathrm{ph}>(/ \mathrm{f} /)$ & $f$ & $\begin{array}{l}\text { Philippo } \rightarrow \text { Filipo } \\
\text { Nympha } \rightarrow \text { ninfa }\end{array}$ \\
\hline$<y, j>(/ i /)$ & $\mathrm{i}$ & $\begin{array}{l}\text { bay } \rightarrow \text { vai } \\
\text { Ceyo } \rightarrow \text { ceio }\end{array}$ \\
\hline$<j>(/ \hbar /)$ (gheada) & gh & prolojos $\rightarrow$ próloghos \\
\hline$<\mathrm{j}, \mathrm{g}>(/ \mathrm{x} /)$ (castelanismos) & $\mathrm{j}, \mathrm{g}$ & Jvan $\rightarrow$ Juan \\
\hline$<\mathrm{n} h, \mathrm{mh}, \mathrm{n} \ldots>/ \mathrm{y} /$ & $\mathrm{nh}$ & $\begin{array}{l}\text { Vn ha cerba Mansa } \rightarrow \text { unha cerva mansa } \\
\text { Umha laranxa } \rightarrow \text { unha laranxa } \\
\text { Hum-ha campaiña } \rightarrow \text { unha campaína } \\
\text { una freira } \rightarrow \text { unha freira } \\
\text { sacaras un a Racion } \rightarrow \text { sacarás unha ración }\end{array}$ \\
\hline$<\mathrm{n}, \mathrm{m}>$ (na marxe silábica) & $\mathrm{n} / \mathrm{m}$ & $\begin{array}{l}\text { canbiar } \rightarrow \text { cambiar } \\
\mathrm{fim} \rightarrow \mathrm{fin}\end{array}$ \\
\hline$<r, R, r r>$ & $\mathrm{r} / \mathrm{rr}$ & onRa $\rightarrow$ honra \\
\hline$<\mathrm{SS}>$ & $\mathrm{s}$ & confesso $\rightarrow$ confeso \\
\hline$<\mathrm{u}, \mathrm{b}, \mathrm{v}>/ \mathrm{b} /$ & $\mathrm{b} / \mathrm{v}$ & $\begin{array}{l}\text { bay } \rightarrow \text { vai } \\
\text { bermello } \rightarrow \text { vermello } \\
\text { viue } \rightarrow \text { vive } \\
\text { alcauela } \rightarrow \text { alcabela }\end{array}$ \\
\hline
\end{tabular}


- Mantense sen alteración a grafía orixinal dos grupos consonánticos: aciòs $\rightarrow$ aciós

tractado $\rightarrow$ tractado

assumpto $\rightarrow$ asumpto

copra $\rightarrow$ copra

blanco $\rightarrow$ blanco

o Mantense $<\mathrm{sc}>$, calquera que sexa a grafía do segundo elemento: nasçido $\rightarrow$ nascido

o Actúase sobre falsos grupos, formados por duplicación: Philippo $\rightarrow$ Filipo

- Exceptúanse da regularización todos aqueles casos en que a grafía evidencia un trazo fonético que, caso de regularizar, quedaría oculto, como é o caso da variación gráfica <s / z> (sapato, tiznada, dizque).

o Redúcense as vogais duplas que non teñen implicacións de carácter fonético:

$\mathrm{fee} \rightarrow \mathrm{fe}$

- Mantense a representación de procesos fonéticos que afectan ao vocalismo átono (ofindido, diárea, bunito...), incluída a paragoxe e a epéntese. Tampouco se restitúe $<$ e $>$ ante $<$ s $>$ líquido.

\section{ANOTACIÓN E LEMATIZACIÓN DOS TEXTOS}

Todos os textos que integran o corpus Gondomar están lematizados e conteñen anotación morfosintáctica. Para a súa anotación adoptouse o sistema de etiquetas EAGLES ${ }^{4}$. O proceso de anotación e lematización desenvolveuse en dúas fases sucesivas. Nunha primera fase, a asignación de etiquetas e lemas realizouse de xeito automático mediante Freeling ${ }^{5}$, unha ferramenta de análise lingüística de código aberto integrada en TEITOK. Nunha segunda fase, os resultados des-

${ }^{4}$ http://www.ilc.cnr.it/EAGLES96/home.html

5 http://nlp.lsi.upc.edu/freeling/index.php/node/1 
te procesamento automático foron revisados e corrixidos manualmente polos editores a través do formulario de edición dos tokens mostrado na figura 1 . As etiquetas e os lemas asignados introdúcense como atributos de cada token no documento xml que contén o texto. Ademais, poden recuperarse en calquera momento simplemente con colocar o cursor sobre calquera das palabras do texto ou con activar o modo de visualización correspondente:
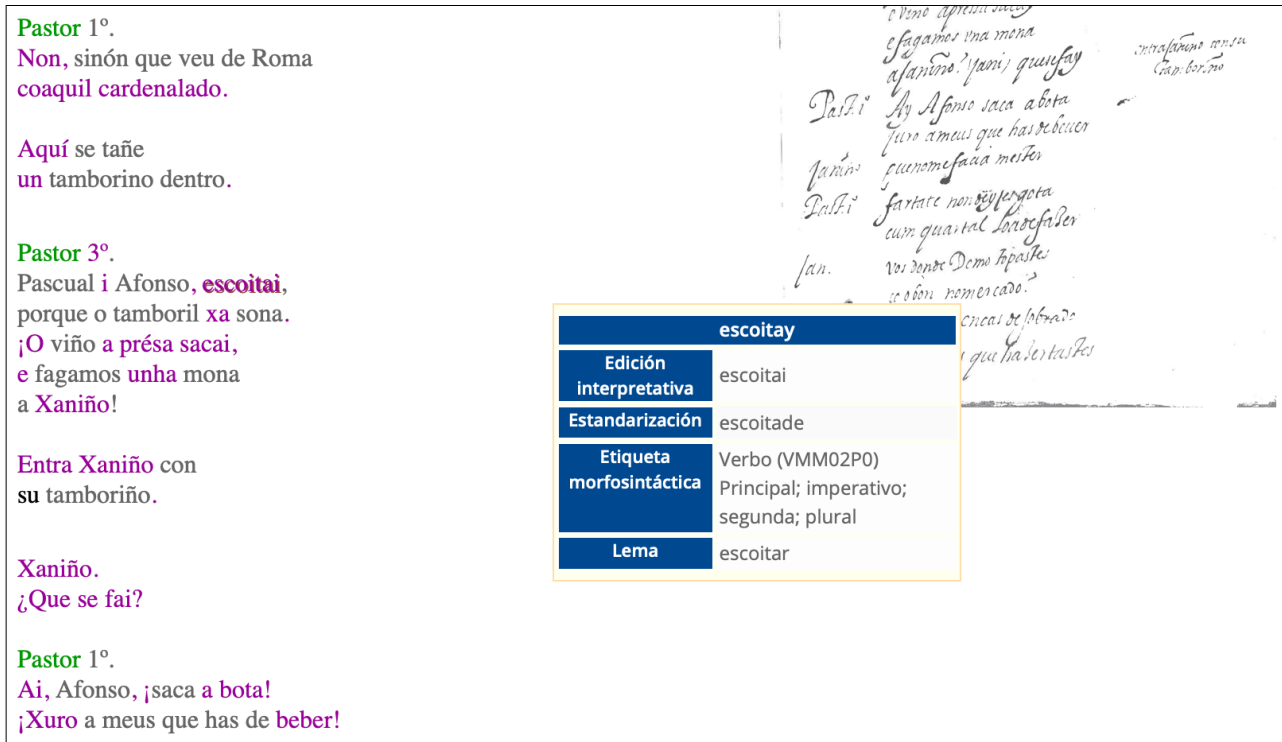

Figura 2. Ventá coas variantes de edición, etiqueta morfosintáctica e lema

\section{VISUALIZACIÓN E EXPLOTACIÓN DOS TEXTOS DO CORPUS}

Gondomar permite visualizar os textos do corpus nos diferentes niveis de edición. En todo momento é posible cambiar de nivel e ter á vista, ao mesmo tempo, a reprodución facsimilar. As intervencións dos editores márcanse no propio texto mediante códigos de cor que a aplicación permite activar ou desactivar de xeito intuitivo. 


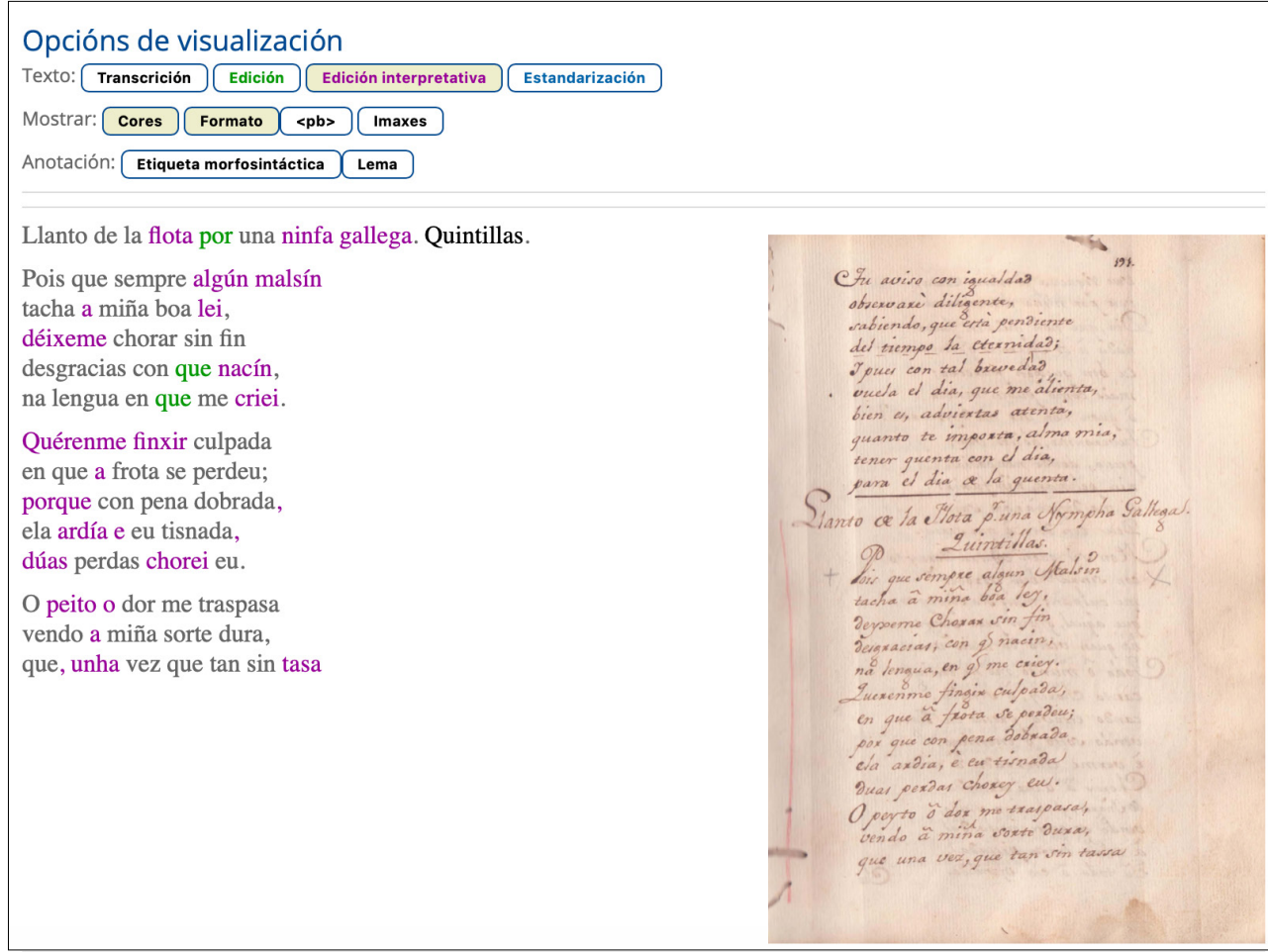

Figura 3. Visualización do facsímil e da edición interpretativa dun texto en Gondomar

Por outra banda, é posible descargar de xeito sinxelo o documento xml correspondente a cada texto, con toda a información introducida no proceso de transcrición, edición, anotación e lematización. Pódense descargar tamén as reproducións facsimilares e a versión txt da edición que se está visualizando.

O corpus ofrece tamén un buscador que permite realizar diferentes tipos de procura no conxunto dos textos compilados ou ben nunha parte deles. 


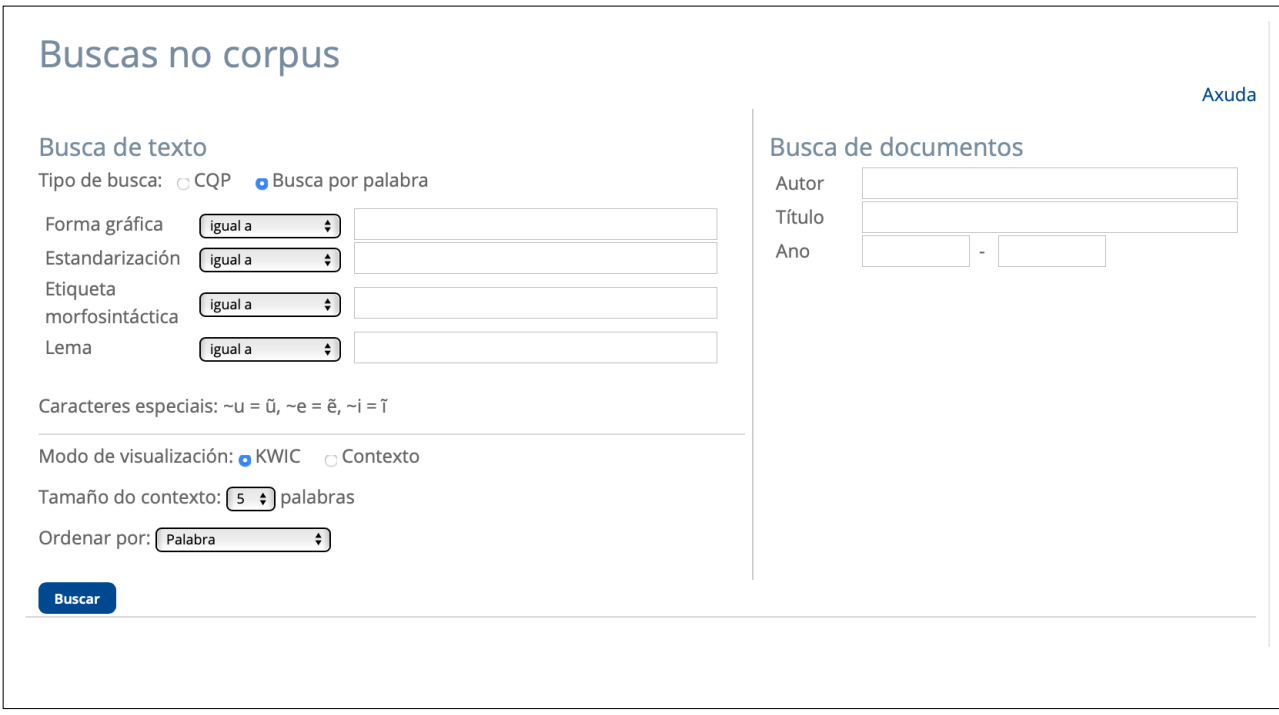

Figura 4. Formulario de buscas en Gondomar

Tal e como se pode apreciar na figura 4, son varias as modalidades de busca que se ofrecen:

- Forma gráfica (word): permite localizar unha palabra tal e como figura orixinalmente nos textos (para localizar, por exemplo, a variante pudiche).

- Estandarización (nform): permite localizar nos textos as variantes dunha palabra na grafía correspondente ao estándar actual (para localizar, por exemplo, todas as variantes que se rexistran nos textos correspondentes á forma estándar actual puideches: puideches, poideches, puideche, pudiche...).

- Etiqueta morfosintáctica (pos): permite localizar nos textos as formas correspondentes a unha determinada etiqueta EAGLES (para localizar, por exemplo, todas as formas que no corpus están etiquetadas como VMIS2S0: segunda persoa de singular do pretérito de indicativo).

- Lema (lemma): permite localizar nos textos as formas correspondentes a un determinado lema (para localizar, por exemplo, todas as ocorrencias no corpus do verbo poder en calquera forma do seu paradigma). 
Naturalmente, é posible tamén realizar buscas combinando dous ou máis dos elementos anteriores (por exemplo, buscar todas as variantes para a forma estándar fuches pertencentes ao lema ir, con exclusión das pertencentes a ser).

Por outra banda, ademais de realizar buscas no conxunto do corpus, pódese limitar a busca a un autor determinado, a unha obra e/ou a un determinado rango de datas.

Finalmente, para calquera operación de busca é posible, seleccionando a opción correspondente no menú despregable, localizar (a) unha palabra ou etiqueta completa, (b) unha palabra ou etiqueta que comeza por unha determinada secuencia de caracteres, (c) unha palabra ou etiqueta que remata nunha determinada secuencia de caracteres, ou (d) unha palabra ou etiqueta que contén unha determinada secuencia de caracteres.

Pódense realizar procuras máis complexas seleccionando CQP como tipo de busca. Deste xeito, pódese, por exemplo, localizar todas as ocorrencias do lema ter seguido dunha preposición calquera:

$$
\text { [lemma="ter"] [pos="SPSO0"]; }
$$

ou ben, unha estrutura formada polo lema ter, seguido da preposición de e dunha forma verbal de infinitivo:

$$
\text { [lemma="ter"] [pos="SPS00" \& lemma="de"] [pos="VMN.*"]; }
$$

ou ben, un posesivo non precedido dunha forma do artigo determinado:

$$
\text { [pos!="DA.*”] [lemma="meu”|lemma="teu”|lemma="seu”]. }
$$

A través desta modalidade de busca é posible tamén cancelar a diferenciación entre maiúsculas e minúsculas:

[word=“miña" \%ci]. 


\section{REFERENCIAS BIBLIOGRÁFICAS}

Álvarez, Rosario / Ernesto González Seoane (2015): «O romancillo da cea do cordeiro, texto galego do século Xviı", en Francisco Dubert García / Gabriel Rei-Doval / Xulio Sousa (eds.): En memoria de tanto miragre. Estudos dedicados ó profesor David Mackenzie. Santiago de Compostela: Universidade de Santiago de Compostela, 21-40.

Álvarez, Rosario / Ernesto GonZález Seoane (2016): «Iluminar los Séculos Escuros: Gondomar, un corpus para el estudio del gallego en la Edad Moderna», en Johannes KabateK (ed.): Lingüística de corpus y lingüistica histórica iberorrománica. Berlin: De Gruyter, 115-136.

Áldvarez, Rosario / Ernesto González Seonne (eds.) (2017a): Gondomar. Corpus dixital de textos galegos da Idade Moderna. Santiago de Compostela: Instituto da Lingua Galega. <http://ilg.usc.gal/gondomar/>.

Álvarez, Rosario / Ernesto González SeoAne (2017b): Gondomar. Corpus dixital de textos galegos da Idade Moderna. Transcrición paleográfica. Criterios (Versión 1). Santiago de Compostela: Instituto da Lingua Galega. <http://ilg.usc.gal/gondomar/PDF/Normas_Paleográfica_01.pdf>.

Álvarez, Rosario / Ernesto González Seonne (2017c): Gondomar. Corpus dixital de textos galegos da Idade Moderna. Edición interpretativa. Criterios (Versión 1). Santiago de Compostela: Instituto da Lingua Galega. <http://ilg.usc.gal/gondomar/PDF/Criterios_Interpretativa_01.pdf>.

Álvarez, Rosario / Xosé Luís Rodríguez Montederramo (2002): «O Diálogo de Alberte e Bieito. Dramaturxia, elites letradas e escrita en galego a fins do século xvI», Boletín da Real Academia Galega 363, 241-311.

Álvarez, Rosario / Xosé Luís Rodríguez Montederramo (2004): «Escrita epistolar en galego: a correspondencia de don Diego Sarmiento de Acuña, I Conde de Gondomar (1567-1626) (I)», Boletín da Real Academia Galega 365, 253-291.

Álvarez, Rosario / Xosé Luís Rodríguez Montederramo (2005): «Escrita epistolar en galego: a correspondencia de don Diego Sarmiento de Acuña, I Conde de Gondomar (1567-1626) (II)», Boletín da Real Academia Galega 366, 225-303.

Cortijo, Antonio / Miguel Zugasti (2016): Adiciones al corpus dramático español del siglo XVI. La Comedia de la invención de la sortija, partes I y II (Monforte de Lemos, 1594). Pamplona: Eunsa.

González Montañés, Julio I. (2007): «La égloga De Virgine Deipara y el teatro de los jesuitas en Galicia durante la Edad Moderna», Anuario del Instituto Ignacio de Loyola/Loiolako Inazio Institutuen Urtekaria 14, 247-286.

GonZÁlez SeOANE, Ernesto (2019): «Estereotipos e iconización nas representacións do portugués en textos galegos da Idade Moderna», en Ernestina Carrilho / Ana Maria Martins / Sandra Pereira / João Paulo Silvestre (orgs.), Estudos linguisticos e filológicos oferecidos a Ivo Castro. Lisboa: Centro de Linguística da Universidade de Lisboa, 739-763. <http://hdl.handle.net/10451/39619>.

Janssen, Maarten (2016): "TEITOK: Text-Faithful Annotated Corpora», en Proceedings of the Language Resources and Evaluation Conference (LREC 2016) ELRA. Portorož, Slovenia, 4037-4043.

Joseph, John Earl (1987): Eloquence and power. The rise of language standards and standard languages. London: Frances Pinter. 
KaвateK, Johannes (2006): "Tradiciones discursivas y cambio lingüístico», en Guiomar Ciapuscio et al. (eds.): Sincronia y diacronia de tradiciones discursivas en Latinoamérica. Madrid: Iberoamericana/Vervuert, 151-172.

КАвАтек, Johannes (2007): «Las tradiciones discursivas entre conservación e innovación», Rivista di Filologia e Letterature Ispaniche 10, 331-345.

KLoss, Heinz (1967), “'Abstand languages' and 'Ausbau languages'», Anthropological Linguistics 9:7, 29-41. 
